\title{
Analysis of hospital interior air quality audits
}

\author{
Lee-Kuo Lin ${ }^{\mathrm{a}}$, Yan-Sin Cai and Yao-Chien Tsai \\ Department of Civil Engineering, National Taipei University of Technology, Taipei 106, Taiwan
}

\begin{abstract}
In general, people spent more than $80 \sim 90 \%$ of living time in the indoor every day, human health and indoor environmental quality are closely related. The hospital has a complex and unique environmental characteristics, medical personnel and patients are prolonged exposed to risk factors in a variety of environments. Therefore, the merits of indoor air quality in the hospital, not only has a threat to the health of medical personnel and patients, but also will directly affect the quality and efficiency of health care work. A regular monitoring can, improve and maintain a well of indoor air quality, thus ensuring the safety maintenance of medical personnel and patients in hospital, it has become an important issue for hospital. This study has literatures review to collate and analyse that are related issues with indoor air quality. Then measures the indoor air quality test with direct-reading instruments. In selected hospital of this study were field-tested, then use the measured data in the field, discussion and analysis of the causes of air pollutants and the establishment of the sensing area of pollutants Concentration empirical mode.
\end{abstract}

\section{Introduction}

In recent years, as environmental awareness promotion, indoor air quality and harm to people's health issues more attention, Taiwan is the world's second country indoor air quality legislation. People per day on average, about 80 90\% time in indoor environments, Indoor environmental quality and human health related, poor indoor air quality can lead to sick building syndrome, legionellosis and other various diseases of indoor environmental quality is at stake.

Hospitals have complex and special environmental characteristics, indoor air quality requirements are also relatively more stringent, health care workers are exposed to different risk factors for a long time in the environment of, so the quality of indoor air quality, Will threaten the health of medical staff and the quality of care and efficiency. In addition, the long stay patient in the hospital, Because of its body has been weak, poor immune system, More vulnerable to the effects of poor indoor air quality, Therefore, how to monitor, on a regular basis to improve and maintain good indoor air quality, And ensuring the safety of health care workers and hospital patients maintain hospital has become an important topic.

Implementation of this research purposes is to discussion on indoor air quality for hospitals, research purposes include the following:

(1) On the actual hospital indoor air quality testing, understanding hospital indoor air $\left(\mathrm{CO}_{2}\right)$, (HCHO), $\left(\mathrm{PM}_{10}\right)$ levels.

\footnotetext{
${ }^{\mathrm{a}}$ Corresponding author : lklin@ ntut.edu.tw
} 
(2) Collection and analysis of relevant literature, medical home indoor air quality may be affected by factors, and the effect type, characteristics, source, through data analysis to analyze of causes of air pollution.

(3) Through the characteristics of the highly correlated pollutants and environmental factors, Using data analysis, Establish concentrations of pollutants in the area experience formula , Assessing the degree of pollution, determine whether the three pollutants in hospitals out of indoor air quality standard.

\section{Main contents}

\subsection{Indoor air quality and health}

According to the Bulletin of the Republic of China Executive Yuan's Environmental Protection Department the purpose of "indoor air quality management Act," definition of article III of the "indoor" refers to the use of the public buildings of closed or semi-closed spaces, and the public means of transport to take the space. "Indoor air quality" refers to the presence in indoor air after longterm exposure is sufficient to directly or indirectly to prejudice the health or living conditions of substance, Include carbon dioxide, carbon monoxide, formaldehyde and total volatile organic compounds, bacteria, fungi, particle size less than or equal to ten Micron particulate matter $\left(\mathrm{PM}_{10}\right)$, particle size less than or equal to the second. Five microns particulate matter $\left(\mathrm{PM}_{2.5}\right)$ and ozone and other substances designated by the central competent authority notice concentrations, air humidity and temperature.

World in view of indoor air pollution for the public health impact or potential threats, according to their architectural characteristics and lifestyles of States, invested a lot of resources for research, laws are in place and management programmers, and so on. Overall, the poor air quality on human health hazard in severity can be divided into three different classes (Figure1), First for the sick building syndrome, the second for building-related illness, Third is through research and reasoning are aware of many air pollutants have carcinogenic properties, long time stimulation can affect the heart and blood vessels and chronic respiratory diseases.

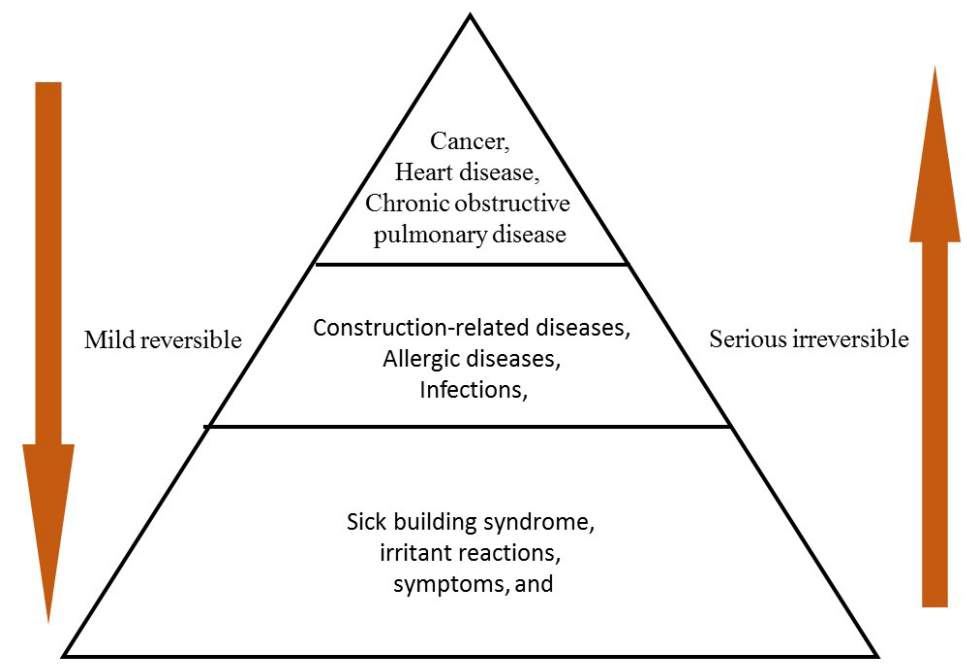

Figure 1. Indoor air quality and health hazards. 


\subsection{Indoor air pollutants}

The national institute for occupational safe and health, investigation and analysis of indoor air quality, sources of indoor air pollutants include outdoor and indoor human activities, indoor air conditioning systems, building materials, equipment and supplies, and indoor sources of organic matter, such as the six, pollutants and sources is shown in table1.

Table 1. Indoor environmental pollution source and pollutant

\begin{tabular}{|c|c|c|}
\hline \multicolumn{2}{|r|}{ Pollution Source } & Pollutant \\
\hline \multirow{3}{*}{ Outdoor air } & Stationary sources & $\mathrm{SO}_{2}, \mathrm{O}_{3}$,Dust,CO,Hydrocarbon,Other toxic substances \\
\hline & Mobile sources & CO,Dust,Nitrogen oxides, Oxysulfide, Lead \\
\hline & Soil & Radon, Microorganism (Bacteriumgerm, Fungifungus.) \\
\hline \multirow{3}{*}{$\begin{array}{l}\text { Indoor } \\
\text { human } \\
\text { activities }\end{array}$} & Human activities & $\mathrm{CO}_{2}$, Vapor, Bad smell,Microorganism \\
\hline & Smoke & $\begin{array}{l}\text { Dust, } \mathrm{CO}, \mathrm{CO}_{2}, \text { Ammonia,Nitrogen oxides, Hydrocarbon, } \\
\text { Volatile organic contaminants,Carcinogenic compounds }\end{array}$ \\
\hline & Spray & Fluorocarbon, Bad smell,Volatile organic contaminants \\
\hline \multirow{2}{*}{$\begin{array}{c}\text { Air } \\
\text { conditioning } \\
\text { system }\end{array}$} & Air handling unit & Fungifungus,Allergen ,Bacteriumgerm, Bad smell \\
\hline & Air conditioner line & Dust,Fiber,Fungifungus,Allergen, Bacteriumgerm \\
\hline \multirow{3}{*}{$\begin{array}{l}\text { Building } \\
\text { materials }\end{array}$} & Concrete, stone & Radon \\
\hline & $\begin{array}{l}\text { Inorganic mineral board, } \\
\text { Plywood, Carpetrug, Furniture }\end{array}$ & $\mathrm{HCHO}$, Volatile organic contaminants \\
\hline & $\begin{array}{l}\text { Insulating materials, Insulation } \\
\text { or fireproofing materials }\end{array}$ & HCHO, Glass fiber,Asbestos, Volatile organic contaminants \\
\hline \multirow{3}{*}{$\begin{array}{l}\text { Equipment } \\
\text { and supplies }\end{array}$} & Burning appliances & $\mathrm{CO}_{2}, \mathrm{CO}$, Nitrogen oxide, Hydrocarbons, Dust \\
\hline & $\begin{array}{c}\text { Service machines } \\
\text { (Copier,Clean machine) }\end{array}$ & $\mathrm{O}_{3}$, Dust,Bacteriumgerm, Fungifungus \\
\hline & Other & $\begin{array}{l}\text { Stationery solvent, Fungicide,Pesticides, Volatile organic } \\
\text { contaminant }\end{array}$ \\
\hline \multirow{3}{*}{$\begin{array}{c}\text { Indoor } \\
\text { organic } \\
\text { material }\end{array}$} & Perishable foods & Fungifungus, Bad smell \\
\hline & Plants and flowers & Pollen, Fungifungus \\
\hline & Waste & Ammonia,Allergen, Bacteriumgerm \\
\hline
\end{tabular}

This study only $\mathrm{CO}_{2}, \mathrm{HCHO}$ and $\mathrm{PM}_{10}$, three projects, Learn about indoor air pollutants will help to judge the sources of pollutants and control, improve indoor air quality and human health, the following will be described in detail for three pollutants.

\section{(1) $\mathrm{CO}_{2}$}

$\mathrm{CO}_{2}$ is a colorless, odorless and nonirritating gas, not toxic, Low concentrations are harmless to the human body, and High concentration has an impact on human health. Sources of $\mathrm{CO}_{2}$ produced by human breathing as the main source. Concentration is usually with density and ventilation efficiency has great relevance. $\mathrm{CO}_{2}$ concentration on human physiological effects as shown in table2.

Table 2. Effects of $\mathrm{CO}_{2}$ concentration on the body

\begin{tabular}{|c|l|}
\hline Concentration (ppm) & \multicolumn{1}{c|}{ Physiological responses } \\
\hline$\leqq 600$ & No \\
\hline $600 \sim 1000$ & Occasional headaches, Lethargy, Sultry \\
\hline $1000 \sim 10000$ & Respiratory and circulatory organs and brain function is affected \\
\hline $10000 \sim 30000$ & Breathing speeds up, face the warm feeling \\
\hline $30000 \sim 40000$ & Ringing in the ears, Headache, Increased blood pressure \\
\hline $40000 \sim 60000$ & Vascular dilatation of the skin, Nausea, Vomiting \\
\hline $70000 \sim 80000$ & Mental confusion, Difficulty in breathing \\
\hline $80000 \sim 100000$ & Mental confusion, Convulsions, Respiratory arrest \\
\hline $100000 \sim 200000$ & Central nervous system disorders, Life-threatening \\
\hline
\end{tabular}




\section{(2) $\mathrm{HCHO}$}

$\mathrm{HCHO}$ is a transparent and pungent gas, its extensive use in man-made sheet metal, plastic flooring, synthetic materials, coatings and adhesive. Table 3 is Effects of HCHO concentration on the body past animal and human epidemiological and toxicological data confirmed HCHO exposure, In addition to causing stimulation of the eyes, skin, throat, and is one of the chemicals that cause human cancer, International Agency for Research of Cancer was HCHO in 2006 as a definite human carcinogen. Indoor $\mathrm{HCHO}$ main source is dominated by furniture or use of a product, such as furniture or wood products on the surface of the adhesive, wallpapers, cleaning agents, or electronic devices is one of the sources. In addition, indoor decoration materials such as Styrofoam, insulation, adhesive materials, fabrics, carpets and floor layout with $\mathrm{HCHO}$, And thus, $\mathrm{HCHO}$ levels to determine the health of the test building materials building materials one of the most important projects.

Table 3. Effects of HCHO concentration on the body

\begin{tabular}{|c|l|}
\hline Concentration $(\mathbf{p p m})$ & \multicolumn{1}{c|}{ Effect } \\
\hline $0.1 \sim 0.3$ & Minimum trigger amount \\
\hline 0.8 & Bad smell \\
\hline $1.0 \sim 2.0$ & Micro stimulation \\
\hline $2.0 \sim 3.0$ & Eye, nose and throat stimulation \\
\hline $4.0 \sim 5.0$ & Mucous membrane irritation involuntary tears \\
\hline $10.0 \sim 20.0$ & Severe burning sensation, cough can only be tolerated for a few minutes \\
\hline $50.0 \sim 100.0$ & Seriously hurt in 5-10 minutes \\
\hline
\end{tabular}

\section{(3) $\mathrm{PM}_{10}$}

Suspended particulates are tiny particles floating in the air, and the severity of harm to human health depends on the particle size, When the particle size is smaller, easier to enter the body of tracheal or Broncho alveolar region. Particles smaller than $2.5 \mu \mathrm{m}$ particles, known as $\mathrm{PM}_{2.5}$, Deposition in the lungs of the efficiency is the highest, and deposit resistance will harm human respiratory function, Allergic rhinitis, asthma, chronic obstructive pulmonary disease and other diseases, Effects of Suspended particles concentration on the body as shown in table4.

Table 4. Effects of Suspended particles concentration on the body

\begin{tabular}{|c|c|c|}
\hline $\begin{array}{c}\text { Concentration } \\
\left(\mathrm{mg} / \mathrm{m}^{3}\right)\end{array}$ & Effect & Notes \\
\hline 0.15 & Increase the frequency of asthma & \multirow{4}{*}{$\begin{array}{l}\text { Increased mortality when } \\
\text { is above } 0.1 \mathrm{mg} / \mathrm{m}^{3}\end{array}$} \\
\hline 0.23 & To reduce the FEV1.0 & \\
\hline 0.35 & Influence of pulmonary function of chronic disease patients & \\
\hline 0.35 & $\begin{array}{l}\text { Increase in respiratory tract of patients with chronic } \\
\text { bronchitis symptoms }\end{array}$ & \\
\hline
\end{tabular}

\subsection{Data analysis and discussion}

Detection in all test points in 8 hours, Living factors of temperature and relative humidity, Chemical factors on $\mathrm{CO}_{2}$ and $\mathrm{HCHO}$ and physical factors in aerosols of size less than or equal to 10 microns $\left(\mathrm{PM}_{10}\right)$, choose the average regression analyses.

Table 5. Correlation between chemical pollution pointer- $\mathrm{CO}_{2}$

\begin{tabular}{|c|c|c|c|c|}
\hline $\mathrm{CO}_{2}$ Pointer & $\begin{array}{c}\text { High positive } \\
\text { correlation }\end{array}$ & $\begin{array}{c}\text { Moderate } \\
\text { positive } \\
\text { correlation }\end{array}$ & $\begin{array}{c}\text { High negative } \\
\text { correlation }\end{array}$ & $\begin{array}{c}\text { Moderate } \\
\text { negative } \\
\text { correlation }\end{array}$ \\
\hline Indoor temperature & 0.846 & & & \\
\hline Outdoor temperature & 0.828 & & & \\
\hline Indoor $\mathrm{PM}_{10}$ & & 0.590 & & \\
\hline Outdoor $\mathrm{PM}_{10}$ & & 0.429 & & \\
\hline
\end{tabular}


(1) $\mathrm{CO}_{2}$ concentrations influence factor analysis

$\mathrm{CO}_{2}$ concentrations affect indoor pollutant concentrations of important factors and correlation of factors, to detect the average data using statistical methods to further some factor of its relevance, as shown in table5. $\mathrm{CO}_{2}$ show in the pointer in the statistical results to the indoor temperature, outdoor temperature Max.

(2) HCHO concentrations influence factor analysis

Establishment of HCHO concentrations affect indoor pollutant concentrations of important factors and correlation of factors, to detect the average data using statistical methods to further some factor of its relevance, as shown in table6. HCHO statistical outcome, the pointer appears to be indoor humidity maximum.

Table 6. Correlation between chemical pollution pointer-HCHO

\begin{tabular}{|c|c|c|c|c|}
\hline HCHO Pointer & $\begin{array}{c}\text { High positive } \\
\text { correlation }\end{array}$ & $\begin{array}{c}\text { Moderate positive } \\
\text { correlation }\end{array}$ & $\begin{array}{c}\text { High negative } \\
\text { correlation }\end{array}$ & $\begin{array}{c}\text { Moderate negative } \\
\text { correlation }\end{array}$ \\
\hline Indoor humidity & 0.729 & & & \\
\hline Outdoor humidity & & 0.628 & & \\
\hline
\end{tabular}

(3) $\mathrm{PM}_{10}$ concentrations influence factor analysis

$\mathrm{PM}_{10}$ concentrations affect indoor pollutant concentrations of important factors and correlation of factors, to detect the average data using statistical methods to further some factor of its relevance, as shown in table7. For $\mathrm{PM}_{10}$ statistical outcome, the pointer displays indoor temperature, outdoor $\mathrm{PM}_{2.5}$ $\mathrm{PM}_{10}$, affected the most. For $\mathrm{PM}_{10}$ statistical outcome, the pointer displays indoor temperature, outdoor $\mathrm{PM}_{2.5} \mathrm{PM}_{10}$, affected the most.

Table 7. Correlation between physical pollution pointer- $\mathrm{PM}_{10}$

\begin{tabular}{|c|c|c|c|c|}
\hline $\mathbf{P M}_{10}$ Pointer & $\begin{array}{c}\text { High positive } \\
\text { correlation }\end{array}$ & $\begin{array}{c}\text { Moderate } \\
\text { positive } \\
\text { correlation }\end{array}$ & $\begin{array}{c}\text { High negative } \\
\text { correlation }\end{array}$ & $\begin{array}{c}\text { Moderate } \\
\text { negative } \\
\text { correlation }\end{array}$ \\
\hline Indoor temperature & 0.760 & & & \\
\hline Outdoor temperature & & 0.634 & & -0.504 \\
\hline Indoor humidity & & & & -0.594 \\
\hline Outdoor humidity & & & & \\
\hline $\mathrm{CO}_{2}$ & & 0.590 & & \\
\hline Outdoor $\mathrm{PM}_{10}$ & 0.887 & & & \\
\hline Outdoor $\mathrm{PM}_{2.5}$ & 0.841 & & & \\
\hline
\end{tabular}

(4) Regression model analysis

Regression analysis on optimization of inspection data, the detection zone can be obtained $\mathrm{CO}_{2}$, $\mathrm{HCHO}, \mathrm{PM}_{10}$ the respective regression model are as follows:

(i) Pharmacies:

$\mathrm{CO}_{2}=364.671+2.304 \times($ Number of people $)-0.004 \times(\text { Number of people })^{2}+2.4 \times 10-6$ $\times(\text { Number of people })^{3}$

$\mathrm{HCHO}=0.189-7.417 /$ (Indoor humidity)

$\mathrm{PM}_{10}=7.039 \times($ Number of people $) 0.348$

(ii) Draw blood:

$\mathrm{CO}_{2}=656.771+1.650 \times($ Number of people $)+0.003 \times(\text { Number of people })^{2}$

$\mathrm{HCHO}=1.3 \times 10-7 \times$ (Indoor humidity) 3.321

$\mathrm{PM}_{10}=48.782-0.059 \times($ Number of people $)+0.002 \times(\text { Number of people })^{2}$

(iii) Registration area:

$\mathrm{CO}_{2}=-294.806+13.280 \times($ Number of people $)-0.046 \times(\text { Number of people })^{2}+5.4 \times 10-$

$5 \times{\text { (Number of people })^{3}}^{3}$

$\mathrm{HCHO}=0.322-13.331 /$ (Indoor humidity)

$\mathrm{PM}_{10}=-55.823+1.030 \times($ Number of people $)$ 


\section{Conclusions and suggestions}

Environmental awareness promotion, has attracted more attention to the health hazards and indoor air quality, Indoor air quality testing equipment in specific medical institutes carry out onsite inspection, to understand indoor air quality changes and features, Conclusions are as follows:

(1) Determine whether the pollutants in hospitals out of indoor air quality standard, Pharmacies are in compliance with the standard, Blood area are $\mathrm{HCHO}$ of five days does not meet standards and $\mathrm{PM}_{10}$ of one day does not meet standards, And the rest are in compliance with, Registered Area are $\mathrm{CO}_{2}$ of two days does not meet standards and $\mathrm{HCHO}$ of one day does not meet standards and PM10 of five day does not meet standards, And the rest are in compliance with.

(2) Through the collection and analysis of data to know, $\mathrm{CO}_{2}$ concentrations, and number, temperature, opening and closing with a high degree of correlation, $\mathrm{HCHO}$ concentrations, climate, and construction, opening and closing a high degree of association, $\mathrm{PM}_{10}$ concentrations, and construction, cleaning, temperature, opening, closing, outdoor $\mathrm{PM}_{2.5}, \mathrm{PM}_{10}$ high outdoor Association

Indoor air quality testing and inspection data analysis, There are still inadequacies can be used as research recommendations:

(1) Recommends that the follow-up could be explored in addition to medical institutions place, the change of indoor air quality and characteristics, and hospitals to compare indoor air quality analysis.

(2) Can continue to discuss the improvement of indoor air quality benefits.

\section{References}

1. Executive Yuan Environmental Protection Agency, Indoor air quality maintenance management specialist staff training materials, Environmental training of personnel of the Executive Yuan EPD (2014)

2. Gold pass stick, Analysis of indoor carbon dioxide concentrations detected - in Changhua County National Primary and Secondary Computer Classroom Case, Large Yeh University, Thesis (2011)

3. S. Q. Luo, and B. X. Chen, Comparative study of management mechanism of countries indoor environmental quality (including air quality), Ministry of the Interior Building Research Institute, Self-study (2006)

4. Xie Yun stiles, Consider the elaboration of localization of indoor air quality indicator of health risk assessment,Taipei University of Technology, Thesis (2003)

5. Y. Y. Li, Research office space Indoor Air Quality Control Strategies, National Cheng Kung University, PhD thesis (2004)

6. S. Hui Zhen, Z. M. Jiang, and L. J. Zhang, Effects of the use of the air conditioning system of the air quality in the business district of the office, NSC / EPD Technical Cooperation Suhui Zhen, Jiang Zheming, Lijun Zhang plans (2000)

7. M. X. Li, Kaohsiung metropolitan area SO2, O3 and PM10 to assess the impact on human health of the, Chaoyang University of Technology, Thesis (2010)

8. Y. T., Architects study indoor air quality - A Case Study in Taichung, Feng Chia University, Thesis (2011) 